\title{
THE DAILY LIFE OF STUDENTS AT ALFREDO PINTO NURSING SCHOOL (1949 - 1956) ${ }^{1}$
}

\author{
Marcia da Rocha Meirelles ${ }^{2}$ \\ Wellington Mendonça de Amorim ${ }^{3}$
}

Meirelles MR, Amorim WM. The daily life of students at alfredo pinto nursing school (1949 - 1956). Rev Latinoam Enfermagem 2008 novembro-dezembro; 16(6):1005-11.

Aim: To analyze students' strategies to adapt to the system established by the dean of Alfredo Pinto Nursing School (1949-1956). Method: This historical-social study uses the thematic oral history to guide data collection. Sources: students' oral statements related to the period from 1949 to 1956 and written documents from the file of the nurse Maria de Castro Pamphiro at UNIRIO. Results: students immediately faced the challenge of adapting to the school's rules regarding eating, clothing, and all changes presented in their daily life. Discussion: They created, along the course, strategies to cheat on rules, adapt to new customs and make life more enjoyable.

DESCRIPTORS: history of nursing; nursing; nursing schools

\section{EL DÍA A DÍA DE LOS ALUMNOS EN LA ESCUELA DE ENFERMERÍA ALFREDO PINTO (1949-1956)}

El objetivo de este estudio fue analizar las estrategias de los alumnos para adecuarse al sistema establecido por la directora de la Escuela de Enfermería Alfredo Pinto, demarcando las transformaciones y sus influencias sobre la vida académica, en el período de 1949 la 1956. El método utilizado fue el estudio de naturaleza histórico social, que utiliza la historia oral temática como método para recolección de datos; las fuentes utilizadas fueron declaraciones orales de los alumnos de la Escuela en el período de 1949 a 1956 y documentos del Archivo Sectorial Enfermera Maria de Castro Pamphiro, de la UNIRIO. Los resultados muestran que las alumnas de inmediato se encontraban con el desafío de adaptarse a las reglas existentes en la Escuela, como la alimentación, el vestuario, en fin, un cambio en lo cotidiano de ellas. Se concluye, aquí, que, en el decorrer del curso, construyeron estrategias que les permitía burlar tales reglas, adaptarse a las nuevas costumbres y a transformar la convivencia en una experiencia placentera.

DESCRIPTORES: historia de la enfermería; enfermería; escuelas de enfermería

\section{O COTIDIANO DOS ALUNOS NA ESCOLA DE ENFERMAGEM ALFREDO PINTO (1949-1956)}

O objetivo deste estudo foi analisar as estratégias dos alunos para se adequarem ao sistema estabelecido pela diretora da Escola de Enfermagem Alfredo Pinto, demarcando as transformações e suas influências sobre a vida acadêmica, no período de 1949 a 1956. O método utilizado foi o estudo de natureza histórico-social, que utiliza a história oral temática como método para coleta de dados; as fontes utilizadas foram depoimentos orais dos alunos da Escola no período de 1949 a 1956 e documentos do Arquivo Setorial Enfermeira Maria de Castro Pamphiro, da UNIRIO. Os resultados mostram que as alunas de imediato se deparavam com o desafio da adaptação às regras existentes na Escola, como a alimentação, a vestimenta, enfim, uma mudança no diaa-dia delas. Conclui-se, aqui, que, no decorrer do curso, construíram estratégias que Ihes permitiam burlar tais regras, se adaptarem aos novos costumes e a tornarem a convivência prazerosa.

DESCRITORES: história da enfermagem; enfermagem; escolas de enfermagem

Escola de Enfermagem Alfredo Pinto, Universidade Federal do Estado do Rio de Janeiro, Brazil:

${ }^{1}$ Project awarded at IV Week - Professor Glete De Alcântara and I Scientific Presentation on History of Nursing, 2007; ${ }^{2}$ Undergraduate student, e-mail: marciameirelles@oi.com.br; ${ }^{3}$ Ph.D in Nursing History, Adjunct Professor, e-mail amorimw@gmail.com. 


\section{INTRODUCTION}

This study looks at the daily routine of students from Alfredo Pinto Nursing School between 1949 and 1956. Its initial point is the year when Law $775 / 1949^{(1)}$ took effect, which regulates nursing teaching in Brazil. The end point is 1956, when the first nurse dean of the school, Maria de Castro Pamphiro, ended her mandate.

This period is marked by several changes in the country's political and economic areas.

The year 1950 is characterized by the return of Getúlio Vargas to the presidency. With the people's approval, he created State and monopolist firms in all infrastructure sectors, such as oil, electricity and steel $^{(2)}$.

In the health area, president Vargas sanctioned Law $1920^{(3)}$ in 1953, creating the Ministry of Health. The offices and services, working at the time under the former Ministry of Education and Health, related to health and child and separated from those that exerted common activities, were transferred to the newly created ministry.

In 1954, the advance of the State's position in the economy started to generate strong reactions against the president. This revolt did not manage to overthrow his government, but the attack against Carlos Lacerda, one of his major opponents, weakened Vargas's position and he preferred to commit suicide than resign ${ }^{(2)}$.

In the following year, Juscelino Kubitschek was elected president. His government was based on a Plan of Goals, where priorities were defined and critical points were identified, to be urgently overcome, in addition to the construction of a new Capital in the country's Central region ${ }^{(2)}$. The country presented considerable growth under Juscelino's government and that was an optimistic time, favored by high levels of economic growth ${ }^{(4)}$.

Nevertheless, the motivation to develop this study originated in events that influenced the course of the first Brazilian nursing school in the mid $20^{\text {th }}$ Century. In 1943, Maria de Castro Pamphiro assumed the direction of the Alfredo Pinto Nursing School (EEAP) and was the first nurse to become dean of this school. After assuming the post, she initiated several changes at the EEAP. The struggle to get the course offered by the school recognized as nursing and no longer nursing auxiliary, as determined by the National Department of Health and included in the 1942 EEAP regulations, is one of the changes that deserves to be highlighted. The aim was to match the same teaching standards of schools like Anna Nery.

This goal was not achieved until 1948, but it was appeased by the Law 775/1949, which regulated nursing teaching in the country. This law marks the history of Brazilian nursing because it ended decree 20 109/1931, which gave the privilege of setting the official standard for the remaining Brazilian nursing schools to Anna Nery Nursing School ${ }^{(5)}$.

The EEAP's dean attempted, during her mandate, to change not only the teaching ministered at the school, but she also introduced religious ceremonies and awards for the best students, she promoted cultural activities, had new uniforms designed, included rituals like the delivery of insignia and cap, among other customs, as presented in her report ${ }^{(6)}$, which possibly generated changes in the school's daily routine.

To acquire knowledge on daily practices, which depend on a large set, difficulty to establish ${ }^{(7)}$, the study on the reconfiguration of the Alfredo Pinto Nursing School was possible because of access to new documentary sources. However, such official documents mainly express opinions and positions of main agents in the psychiatric, public health and nursing areas. Different perspectives can be observed from reports of people who were students in this school at the time when the main changes in its structure occurred.

In this perspective, we present documentary sources from oral reports of subjects who lived in the school during this period and have preserved in their memory information that can contribute to knowledge about the daily life of students from the Alfredo Pinto Nursing School in the mandate of the first nurse dean.

The following objectives were defined: to describe the daily life of EEAP students in the second half of the mandate of Maria de Castro Pamphiro and analyze strategies they used to adapt to the system established by the EEAP dean, highlighting changes and influences on academic life between 1949 and 1956.

This study is justified by the presentation, as the central category, of the routine of students restricted to a nursing school. This proposal contributes to previous works on this theme, with emphasis on 
the study entitled The daily life of nurses of the army in the Brazilian Expeditionary Force in the theater of operations during World War II, Italy (1942-1945) ${ }^{(8)}$.

This study represents a significant contribution to an institutional research called The reconfiguration of the Alfredo Pinto Nursing School in the mandate of the first nurse dean (1943-1956). This work is part of the research line Development of Nursing in Brazil from the research group (CNPq - National Council of Scientific and Technological Development) Laboratory of Research on Brazilian Nursing History - Laphe, Alfredo Pinto Nursing School, Federal University of Rio de Janeiro (UNIRIO). Because it is produced in this laboratorial space, it is characterized as a research practice that improves scientific production $^{(9)}$. Additionally, the production of new versions and interpretations of the EEAP history will encourage other studies in Nursing History by undergraduate and graduate students.

As the "collective memory is, in addition to an achievement, an instrument and object of power"(10), this study grants visibility and prestige to certain events lived by former students, showing group solidarity and the social identity of the Alfredo Pinto Nursing School.

\section{METHOD}

This is a historical-social study using thematic oral history to collect data, which is considered "a modern resource used to elaborate documents, files, and studies regarding people's social life. It is always a history related to the present time and is acknowledged as live history"(11).

The study subjects were alumni of the Alfredo Pinto Nursing School from the period between 1949 and 1956. It was a boarding school that offered courses for the education of nurses and nursing auxiliaries. Thus, students from both courses shared daily life in the school.

A total of 130 nurses and 82 nursing auxiliaries got their degrees at EEAP in the study time frame. However, in the active search for potential subjects (alive women, not resident in the Federal District, in conditions to provide their statement), only ten nurses and two nursing auxiliaries were found. Seven were located in the retirement office of a federal public hospital founded in 1947, two were faculty members of nursing teaching institutions and one was retired from another institution. The nursing auxiliaries were found through an EEAP/UNIRIO professor who knew about the study. After contact by telephone, the seven retired nurses did not accept to participate in the study due to disease or fear to receive an interviewer at their home. One of the nursing auxiliaries was not in conditions to concede the interview. The remaining nurses and one nursing auxiliary agreed to provide their statements.

As the study starting point we appoint the report of the subject who better knows the group's history or with whom one wants to hold the central interview $^{(11)}$. In this study, this person refers to a professor of a private nursing school in Rio de Janeiro, RJ, Brazil.

After the selection of subjects, the data collection process began through semi-structured interviews. A tape recorder and a diary were used, where conditions and impressions of interviews were registered. Statements were identified by the letter $\mathrm{E}$ followed by the number correspondent to the order they were collected in. Interviews one and two were carried out with the same nurse, interview number three with the nursing auxiliary and number four and five with the remaining nurses, totaling five reports from four participants. Male students were not found. All mentioned names are fictitious.

The primary source comprised the students' oral reports, complemented by documents available in the File of nurse Maria de Castro Pamphiro - EEAP/ UNIRIO. As secondary sources, bibliographies related to Nursing History, the trajectory of Brazilian Nursing Schools and the historiography production of the Research Laboratory in Nursing History and Brazilian History were used.

For the analysis of statements, the thematic categorization technique was used. It consists in assigning the essential elements of a set, first by differentiation, and then by regrouping them according to gender (analogy), following previously defined criteria $^{(12)}$.

The study complied with Resolution 196/96 from the National Health Council concerning studies with human beings and was approved by the Research Ethics Committee at UNIRIO. A free and informed consent term was also elaborated. 
After interviews were carried out, interviewees received a grant letter asking the right to keep the cassette tapes with their respective interviews. After reading and checking the transcribed material, they conceded this right to the LAPHE.

\section{RESULTS AND DISCUSSION}

When one tries to define daily routine, the term "day-by-day" immediately comes to mind. This term comprises the life one lives, whether at home, work, school, wherever one passes, where one constructs life, history. Thus, when one tries to identify factors that structure the daily life of a certain group, it is observed that it almost completely depends on relations established between those who compose it, thus "daily life cannot exist without continuous interaction and communication with the other"(13).

The veterans' order(action)

Fresh students had to incorporate the veterans' directions regarding the use of spaces in the EEAP. It represented the difference, which implied a certain level of compliance, between freshmen and veterans. When one is inserted in a new environment, it can immediately be observed that "the reality of daily life is already defined, that is, it is constituted by an order of objectives that were designated as objects before I had entered that environment" ${ }^{\prime(13)}$.

We were called "preliminaries" in the first six months.

So if a preliminary, nowadays it is called freshman, was in the line and one from the third or fourth period wanted to get in line, she would have to give up her place (E2).

There was a certain incompatibility between nursing students and those from the nursing auxiliary program. The veterans demanded respect because they were already there and we were just arriving, first class of nursing auxiliaries (E3).

We were called "prelis". We had no rights, only the right to study. We always had to be the last in line. In everything, we had to be the last ones (E4).

Living together

Students tried, through groups, to adapt to the new customs and to make the environment they lived in as enjoyable as possible, and this was not an easy task for all of them. "The individual needs to be inserted in groups (in the family, school, community), so that a mediation can be established between the individual and customs, norms and ethics of other larger groupings"(14).

We felt at home. When we weren't in practical training, we could play the piano, those who liked to dance, would dance. It was family life. It was very good (E3).

Living together was extraordinary. Imagine being classmates and living together for 24 hours. It was so good that we formed groups not gangs. It meant to study, eat meals, everything in groups of five or six according to affinities. Harmony was perfect including between all groups. There was joy at school, don't know if it was because we were so restricted and everything was a satisfaction for us (E2). We had no problem at all. We would get to know colleagues over time, from other classes, the veterans always had preference over us, we dreamed about getting there so we'd have the same privileges and "mistreat" others. The relationship with the professors was very good and they were also good (E4).

Eating Habits

Diet was adequate, that is, five meals were offered daily and served at adequate hours. The report of this activity shows discipline regarding the schedule and number of meals, towards an organization of eating habits, which were probably the most diverse, independently of these students' regional origins.

We had a balanced diet. There were six daily meals, first breakfast, snack at 10, lunch, snack at 3, dinner and a symbolic tea at $10 \mathrm{pm}$. The tea, it was a sure thing, enamel cup, which retains the heat. There was tea everyday. Nobody had to drink it, only those who wanted.(E2).

The food was great. There was bread, cheese, jam and butter in the morning. Some days, would be cake, coffee, milk, bread. Other days, crackers with cheese. Lunch was varied. There would be beans, rice, chicken, baked beef, sometimes, meatloaf cake with potatoes, and there was always salad, always vegetable salad. We always ate vegetables. It was very good. Dinner, when there were leftovers from lunch, we would eat them at dinner. But there was always curdled milk dessert, varied, there was always some dessert. There was no supper (E3).

Clothing

After the first stage, students had to wear the school's uniform according to their respective courses, which according to norms was supposed to be perfectly clean and ironed.

Our uniform was a blue dress and starched white apron and nurses wore only a dress and cap. There were also socks. 
Everything had the right size. All with the same length, everything had to be pretty clean and we had to shine our shoes (E3).

I was admitted at the school in 1953 and was an internal student and wore my own clothes, hairnet, skin color stockings and dark blue shoes. Only after we overcame this stage we would take the internship. Then, we'd get the uniform, which was a blue dress with white collar (...). Then, with additional subjects, we got the white apron and cap. The last uniform was the one from Public Health, which was a blue skirt with white collared blouse (E4).

The rituals

The school had some rituals, which "symbolically transmit social and cultural ideologies"(15), like the delivery of insignia and cap, which marks the nursing student'sn first stage overcome during the course ${ }^{(6)}$. The lady with the lamp and the flag bearer, besides religious rituals, were part of ceremonies performed at school.

Students were chosen for the lamp and flag rituals according to their grades. In the case of the lady with the lamp, I don't know if they also considered behavior, because personal posture and behavior were highly valued, not only at school, but especially during supervised training (E1).

Before going to the supervised training, the dean would call us and give two caps, two for each student. Two caps, two aprons and two dresses. We took care of our caps, aprons and dressers ourselves. Nursing students didn'tn have aprons, only caps (E3).

The school participated in religious events. During special events, the father would celebrate mass and we had permission to practice any religion we wanted as far as we wrote in the book where we were going (E2).

The day we received the cap was very solemn (E4).

Thus, the concern of a nursing school in perpetuating rituals is justified by the intention of making a model of nurse known to society, because institutional rituals bestow new qualities upon the group $^{(16)}$.

The cultural Shock

The EEAP was composed of students from several regions around the country with the most varied cultural styles. Internal dislocation of population had different meanings according to the region. The Northeast presented high negative rate of internal migration because of the rubber crisis. The South and Mid South, on the contrary, presented positive rates of migration. The Federal District ${ }^{(17)}$ was the most attractive center.

I came to Rio de Janeiro from a completely different culture. For me, it was a great shock. Eating habits was the first shock, then clothing and even leisure activities. Because my father was so strict at the time, he wouldn't allow me to ride a bike or even learn how to swim. So, when I got here and saw it was completely different from everything I knew, it was such a radical change, I cried day and night in the first four months at school. It got to the point that the dean told me that, if I continued that way, she'd send me back home. I came from a repressive culture from the smallest State in the country, with a repressive father. That's what led to my difficulties (E2).

Besides students' daily routine, the EEAP had always received male and female students since its creation in 1890. However, for female students from other States, the school worked as a boarding school in the mandate of the first nurse dean. Thus, students who lived together most of the day, had to adapt to the rules established by Maria de Castro Pamphiro. In case some of these rules were not complied with, they had to provide clarification and when necessary, they would get warnings. So they created several strategies to have fun without being caught. Such an environment can be considered "a place of residence and work where a great number of individuals in similar situation, separated from the larger society, lead a close and formally administered life", which is called total institution ${ }^{(18)}$.

Repression as strategy to preserve order

The dean kept a repressive regimen at EEAP, aiming to assure order and respectful behavior from students. The schedule had to be rigorously followed. Inspectors exerted great control over students' departures and arrivals, besides meal hours, bedtime, studying hours among others. These institutions were considered "hothouses to change people; each one is a natural experiment on what can be done to the self. (...) The novice has to be placed in a new culture: language, beliefs and schedule"(18)

The attitude the dean generally adopted, in case people disregarded rules, was suspension. You'd stay in the school, with no classes, in the same building, to finish only after graduating. That was what happened to me. I paid 45 days of suspension, only because I had mumps for ten or twelve days, she (dean) said I had allowed it to happen to me (E2).

After dinner we'd finish our chores, some garment we had to fix, shoes to clean, besides the right times to go to bed, which was at 9PM. We couldn't go to bed later than 9PM (E3). 
We had to adapt to the classes, meals and baths schedule, bedtime, all that. [...] I remember that we could only leave school twice a month to go home, as I remember, it was on Fridays and we would come back on Sunday night, by 10, because we had to sign departures and arrivals in the book at the reception. At 10 we had to be inside school (E4).

Forms of resistance

Students sought many ways to resist the stringent system implemented at EEAP. If they were caught, they would have to provide clarification to the dean and, if necessary, they would get a warning. It shows a characteristic of institutions where "those in command tend to feel superior and correct; pupils tend, at least under some aspects, to feel inferior, weak, reproachful and guilty"(18).

O Aloprado [The cuckoo] was a newsletter we created, there were two very naughty girls in my class, one from Rio and the other from Minas Gerais, (...) they were extremely intelligent One day they decided to create a club and a newsletter. The club was called "Conosco Ninguém Podemos" [Nobody can deal with us] and the newsletter "O Aloprado". We'd published the most varied things, our intimacy in code, what was read would not be understood and nobody would know who was who (E1).

Strategies found by students

To be able to escape the inflexibility established by the dean, students elaborated diverse plans. That was the way they found to get free from the oppressive system existent at the school and manage to have fun the way they wished. Punishment was, most of the times, related to the supervised training. Thus, those who were caught would have to comply with a heavier internship workload.

We wouldn't tell the true, we'd say we'd go to the church Nossa Senhora do Brasil, but in fact we'd go to the beach and when we'd get back it would be as if we'd gone to the mass. If we went to the mass we could go out twice on Sundays. If we said

\section{REFERENCES}

1. Ministério da Saúde (BR) Enfermagem : Legislação e Assuntos Correlatos. 3a ed. Rio de Janeiro (RJ); 1974.

2. Caldeira J, Carvalho F, Marcondes C, Paula SG. Viagem pela História do Brasil. 2a ed. São Paulo (SP): Companhia das Letras; 1997.

3. Senado Federal (BR) Lei no 1920 cria o Ministério da Saúde. Rio de Janeiro (DF): Senado Federal; 1953. we'd gone to the beach we had to get back at 9PM, but if we said we'd gone to the mass, we could come back at 9:30, 10PM, put on some clothes and go out for the night (E2).

Sometimes we'd run away, but Luisa would put her chair in front of us and keep an eye on us. There was no way to go to the National Radio. Our weak spot was going to the National Radio and riding on streetcars (E3).

\section{CONCLUSION}

The routine of students, who came from several regions of the country with the most diverse cultural styles, at EEAP during the time it was directed by Maria de Castro Pamphiro was a challenge. Even facing new customs, standards and a strongly preestablished hierarchy, they adapted and kept harmonious relations among them. They tried to form groups so as to create new forms of common life, similar to what they were familiar with, so they conformed to new eating habits, to the rules established by the dean, clothing, etc. Such strategies helped the group to survive the 24 hours of the day with strangers at first, but who would later become familiar. The hierarchical issue had a differential depending on how long one was in the institution. As fresh students spent more time in the institution they became veterans. However, this hierarchical relation was harsher on students from the nursing auxiliary program. Students who lived the professionalization process in the social scope of EEAP maintained the hierarchy and control over the fresh students.

In this perspective, resistance strategies were also observed. These strategies attempted to cheat on rules implemented at the school. Students would elaborate strategies to resist and escape the control over young and feminine bodies. Strategies similar to those used by young ladies in society to move from the family to the public space, that is, a radical change in their daily life.

4. Fausto B. História do Brasil. São Paulo (SP): Universidade de São Paulo; 2000.

5. Amorim WM. A reconfiguração da primeira escola de enfermagem brasileira: a missão de Maria de Castro Pamphiro, 1937-1949.[Tese]. Rio de Janeiro (RJ): Escola de Enfermagem Anna Nery/UFRJ; 2004.

6. Pamphiro MC, diretora. Relatório da direção da Escola de Enfermagem Alfredo Pinto. Rio de Janeiro (DF): Ministério da Saúde; 1953. 
7. Certeau M. A Invenção do Cotidiano. $11^{\mathrm{a}}$ ed. Petrópolis (RJ): Vozes; 2005.

8. Bernardes MMR, Lopes GT, Santos TCF. O cotidiano das enfermeiras do exército na força expedicionária brasileira (FEB) no teatro de operações da $2^{a}$ Guerra Mundial, na Itália (1942-1945). Rev Latino-am Enfermagem 2005 maio-junho; 13(3): 314-21.

9. Oguisso T, Freitas GF. História da Enfermagem: Reflexões sobre o ensino e a pesquisa na graduação. Rev Latino-am Enfermagem 2007 janeiro-fevereiro; 15(1): 171-3.

10. Barreira IA. Memória e História para uma nova visão da enfermagem no Brasil. Rev. Latino-am. Enfermagem 1999 julho; 7(3): 87-93.

11. Meihy JCSB. Manual de História Oral. São Paulo (SP): Loyola; 1998.

12. Bardin L. Análise de Conteúdo. Lisboa: Edições 70; 1977.
13. Berger $\mathrm{PL}$, Luckmann T. A construção social da realidade. 26a ed. Petrópolis (RJ): Vozes; 1996.

14. Eller A. O Cotidiano e a História. 7a ed. São Paulo (SP): Paz e Terra; 2004.

15. Silva OC Junior. "Pan - Padrão Anna Nery": a instituição da identidade profissional da enfermeira no Brasil.[Tese]. Rio de Janeiro (RJ): Escola de Enfermagem Anna Nery/UFRJ; 2000 .

16. Santos TCF, Lopes GT, Porto F, Fonte AS. Resistência à liderança norte-americana na formação da enfermeira brasileira (1934-1938). Rev Latino-am Enfermagem 2008 janeiro-fevereiro; 16(1): 130-5.

17. Bessa MN, Amorim WM. Aspectos da formação profissional na Escola de Enfermagem Alfredo Pinto, 1943 a 1949. Esc Anna Nery Rev Enferm 2006 abril; 10 (1): 64-74. 18. Goffman E. Manicômios, Prisões e Conventos. 7a ed. São Paulo (SP): Perspectiva; 2001. 